\title{
Insulin Receptor Substrate-1 (IRS-1) Distribution in the Rat Central Nervous System
}

\author{
Franco Folli, ${ }^{1}$ Luca Bonfanti, ${ }^{2}$ Eric Renard, ${ }^{1}$ C. Ronald Kahn, ${ }^{1}$ and Adalberto Merighi ${ }^{2}$ \\ ${ }^{1}$ Research Division, Joslin Diabetes Center, Department of Medicine, Brigham and Women's Hospital, and Harvard \\ Medical School, Boston, Massachusetts 02215 and 'Dipartimento di Morfofisiologia Veterinaria, Università di Torino, \\ 1-10126 Torino, Italy
}

Insulin receptor substrate 1 (IRS-1) is the primary cytosolic substrate of the insulin and insulin-like growth factor-I (IGF1) receptors. Following tyrosine phosphorylation IRS-1 binds to and activates specific proteins containing SH2 domains. Using biochemical and immunocytochemical techniques, we have mapped the distribution of IRS- 1 in the CNS of the adult rat and compared it with that of insulin and IGF-I receptors and phosphatidylinositol 3-kinase (PI-3 kinase), a signaling molecule functionally related to IRS-1. Immunoprecipitation and Western blotting experiments demonstrate the presence of substantial amounts of IRS-1, insulin receptor, and PI-3 kinase in the brain.

IRS-1 immunoreactivity is widely distributed in neurons from several areas of the brain and spinal cord. The cerebral cortex, the hippocampus, many hypothalamic and thalamic nuclei, the basal ganglia, the cerebellar cortex, the brainstem nuclei, and the lamina $X$ of the spinal cord are particularly rich of immunopositive nerve cells. In these areas most of the neurons immunoreactive for IRS-1 are also stained by either anti-insulin receptor or anti-IGF-I receptor antibodies as well as PI-3 kinase antiserum. IRS-1 immunostaining was very weak or totally absent in neurons of the olfactory bulb, the supraoptic and paraventricular nuclei, the mesencephalic trigeminal nucleus, and the granule cell layer of the cerebellum, despite the fact that these areas were immunolabeled with antibodies against insulin or IGF-I receptors and/or PI-3 kinase. These results show that neurons in the adult rat CNS are endowed with some of the components of the early signaling pathway for growth factors of the insulin/ IGF-I family, although IRS-1 has a distribution distinct from that of the two receptors.

[Key words: insulin receptor substrate 1, insulin-like growth factor I, insulin receptor kinase, insulin-like growth factor I receptor, phosphatidylinositol 3-kinase, CNS, immunocytochemistry]

\footnotetext{
Received Dec. 6, 1993; revised Mar. 21, 1994; accepted Apr. 13, 1994.

This work was partly supported by grants of the Italian Consiglio Nazionale delle Ricerche and Ministero dell'Universitả e della Ricerca Scientifica e Tecnologica and by NIH Grants DK 31036 and 33201 . F.F. was supported by Dottorato di Ricerca (Fisiopatologia Clinica), Università di Milano, Milano, Italy. We are greatly indebted to Drs. Wang and Liu for anti-IGF-I receptor antibodies, and Dr. Gammeltoft for stimulating discussion.

Correspondence should be addressed to Dr. Adalberto Merighi, Dipartimento di Morfofisiologia Veterinaria, Via Nizza 52, I-10126 Torino, Italy.

Copyright (C) 1994 Society for Neuroscience $0270-6474 / 94 / 146412-11 \$ 05.00 / 0$
}

Insulin effects at the cellular level are initiated by ligand binding to the $\alpha$-subunit of the insulin receptor and activation of the tyrosine kinase present in the $\beta$-subunit (Massague et al., 1981; Kasuga et al., 1982). Insulin receptor activation leads to tyrosyl phosphorylation of a cytosolic protein with an apparent molecular weight of 160-185 kDa named insulin receptor substrate 1 (IRS-1) both in vivo and in vitro (White et al., 1985; Rothenberg et al., 1991; Sun et al., 1991, 1992; Hadari et al., 1992; Saad et al., 1992). IRS-1 is highly serine phosphorylated in the basal state and undergoes rapid tyrosine phosphorylation in response to insulin, insulin-like growth factor I (IGF-I), and, in some cells, interleukin 4 (IL-4) (White et al., 1985; Sun et al, 1991; Myers et al., 1993; Wang et al., 1993a,b). One mechanism by which IRS-1 transmits insulin signaling inside the cells is binding of the molecule to $\mathrm{SH} 2-\mathrm{SH} 3$ containing proteins via specific YMXM/YXXM motifs (Cantley et al., 1991; Koch et al., 1991; Folli et al., 1992; Myers and White., 1993; Sun et al., 1993). Among these $\mathrm{SH} 2$ domain proteins, one of the better characterized is the regulatory subunit of phosphatidylinositol- 3 kinase (PI-3 kinase), also referred to as p85. PI-3 kinase activity is stimulated by a variety of growth factors, including insulin, IGFI, NGF, epidermal growth factor (EGF), and following cellular transformation (Whitman et al., 1985; Endeman et al., 1990; Soltoff et al., 1992; Cantley et al., 1991; Hiles et al., 1992; Lapetina et al., 1992; Obermeier et al., 1993). After insulin stimulation either in vivo or in vitro, PI-3 kinase associates with specific YMXM/YXXM motifs in IRS-1 and is activated by this association (Sun et al., 1991, 1992; Backer et al., 1992a; Folli et al., 1992; Hadari et al., 1992).

Insulin, IGF-I and IGF-II receptors, are widely expressed in both the developing and adult mammalian CNS, as demonstrated by autoradiography and immunocytochemistry (Posner et al., 1974; Havrankova et al., 1978; Gammeltoft et al., 1985, 1990; Hill et al., 1986; Bohannon et al., 1988; Lesniak et al., 1988; Ocrant et al., 1988; Unger et al., 1989, 1991a,b; Moss et al., 1990; King and Baskin, 1991). Likewise, biochemical and Northern blot analyses indicate that IRS-1 and PI-3 kinase are also present in the CNS at high concentrations (Cohen et al., 1990; Skolnik et al., 1991; Sun et al., 1992; Araki et al., 1993; this study). However, the topographic and cellular distribution of these molecules in the brain has not yet been investigated. To shed some light on the possible role of these early components of the insulin/IGF-I signaling pathway in the CNS, we have mapped the distribution of IRS-1 in the rat brain and spinal cord and compared it with the immunocytochemical localization of PI-3 kinase, insulin receptors, and IGF-I receptors. 


\section{Materials and Methods}

Materials. Reagents for sodium dodecyl sulfate-polyacrylamide gel electrophoresis (SDS-PAGE) and immunoblotting were from Bio-Rad (Richmond, CA). Protein A-Sepharose 6MB was purchased from Pharmacia (Upsala, Sweden), ${ }^{125}$ I-protein A from ICN Biomedicals (Costa Mesa, CA); nitrocellulose paper (BA 85, $0.2 \mu \mathrm{m}$ ) from Schleicher and Schuell (Keene, NH), sodium amobarbital (Amytal) and human recombinant insulin (Humulin R) from Lilly (Indianapolis, IN). All other reagents were from Sigma Chemical Co. (St. Louis, MO).

Animals. Male rats (130-180 gm; $n=15)$ and mice (6-8 weeks; $n=$ 4) were obtained from Charles River Breeding Laboratories Inc. (Wilmington, MA). They were fed standard rodent chow and water ad libitum. All mice and five rats were used in insulin stimulation experiments in vivo, the remaining rats were employed for immunocytochemical analysis.

Antibodies. Anti-IRS-1 antibodies were raised using two synthetic peptides (CT and NT) derived from the carboxy-terminal (TYASINFQKQPEDRQ) and the amino-terminal (MASPPDTDGFSDVRKVGY) amino acid sequence of the rat liver IRS-1 protein (Sun et al., 1991). They were partially purified either with a protein ASepharose column (anti-CT-IRS-1 antibodies; Folli et al., 1993) or on a peptide affinity column (anti-NT-IRS-1 antibodies; Cheatham et al., 1993). Anti-insulin receptor ( $\alpha$-subunit) antibodies (Rosenzweig et al., $1990)$ were from UBI (Lake Placid, NY). Anti-insulin receptor ( $\beta$-subunit) antibodies were raised in rabbits using a synthetic peptide derived from the carboxy-terminal amino acid sequence (KKNGRILTLPRSNPS) of the $\beta$-subunit of the rat insulin receptor. Anti-IGF-I receptor $(\beta-$ subunit) antibodies (a kind gift of Drs. Wang and Liu, Mount Sinai Medical Center, New York, NY) have been previously described and characterized (Liu et al., 1992). Polyclonal anti-phosphotyrosine antibodies were raised in rabbits and affinity purified on phosphotyramine columns, as previously described (Pang et al., 1985). The anti-rat PI-3 kinase polyclonal antiserum (raised against the $85 \mathrm{kDa}$ subunit of the enzyme) was from UBI (Lake Placid, NY).

Biochemistry: insulin stimulation in vivo. Food was withdrawn 12 $14 \mathrm{hr}$ before experiments; mice and rats were anesthetized with sodium amobarbital $(15 \mathrm{mg} / \mathrm{kg}$ of body weight, i.p) and were used 10-15 min later. The abdominal cavity was opened and $1 \mathrm{ml}$ of normal saline $(0.9 \%$ $\mathrm{NaCl}$ ) with or without $200 \mu \mathrm{g}$ of insulin was injected into the portal vein. The hindlimb skeletal muscles and the brain were excised respectively 1.5 and $2.5 \mathrm{~min}$ after insulin injection and frozen in liquid nitrogen. Frozen tissues were ground into a fine powder and immediately homogenized in ice cold solubilization buffer $(1: 6 \mathrm{w} / \mathrm{v})$ with a Polytron PTA 20S generator (Brinkmann Instruments), as previously described (Folli et al., 1992). Insoluble material was removed by centrifugation at $50,000 \mathrm{rpm}$ in a $70 \mathrm{Ti}$ rotor (Beckman) for $50 \mathrm{~min}$. One milliliter aliquots of the supernatants (protein concentration, $10 \mathrm{mg} / \mathrm{ml}$ ) were used as a sample for immunoprecipitation with anti-insulin receptor $\beta$-subunit $(0.5 \mu \mathrm{g} / \mathrm{ml})$, anti-NT-IRS- $1(0.2 \mu \mathrm{g} / \mathrm{ml})$, and anti-PI-3 kinase (whole antiserum, 1:200 final dilution) antibodies and protein A-Sepharose. Samples were then processed for SDS-PAGE and Western blotting as previously reported (Folli et al., 1992). Blots were finally incubated with anti-phosphotyrosine $(0.3 \mu \mathrm{g} / \mathrm{ml})$, anti-insulin receptor $\beta$-subunit $(0.5 \mu \mathrm{g} / \mathrm{ml})$, anti-IRS-1 (anti-CT-IRS-1, $9 \mu \mathrm{g} / \mathrm{ml}$ ), or antiPI-3 kinase antibodies (whole antiserum, 1:200 final dilution), 125I-protein $\mathrm{A}$ and subjected to autoradiography. Protein determination was performed by the Bradford dye method (Bio-Rad, UK) with bovine serum albumin as standard (Bradford, 1976).

Immunocytochemistry. Rats were anesthetized with sodium pentobarbitone ( $>60 \mathrm{mg} / 100 \mathrm{gm}$ body weight, i.p.) and perfused through the aorta with Bouin's solution. The brain and segments of cervical, thoracic, lumbar, and sacral spinal cord were dissected out, cut in pieces, and placed in the same fixative for 6 additional hours. Following dehydration and wax embedding, coronal sections $(8 \mu \mathrm{m})$ representative of the entire CNS were mounted onto poly-L-lysine-coated slides. After inhibition of endogenous peroxidase activity and preincubation in 0.1 M phosphate-buffered saline $\mathrm{pH} 7.4$ (PBS) containing 1\% egg albumin (Sigma Chemicals Co., St. Louis, MO), sections were incubated overnight at room temperature with anti-NT-IRS-1 (1:500 affinity-purified antiserum), anti-insulin receptor ( $\alpha$-subunit, 1:50), or anti-IGF-I receptor ( $\beta$-subunit, 1:100) antibodies. They were subsequently processed according to the avidin-biotin-peroxidase procedure (ABC, Vector, UK), and the peroxidase reaction was developed using the glucose oxidase nickel-DAB method (Shu et al., 1988). Immunocytochemical controls consisted of (1) liquid phase adsorption of the anti-NT-IRS-1 peptide
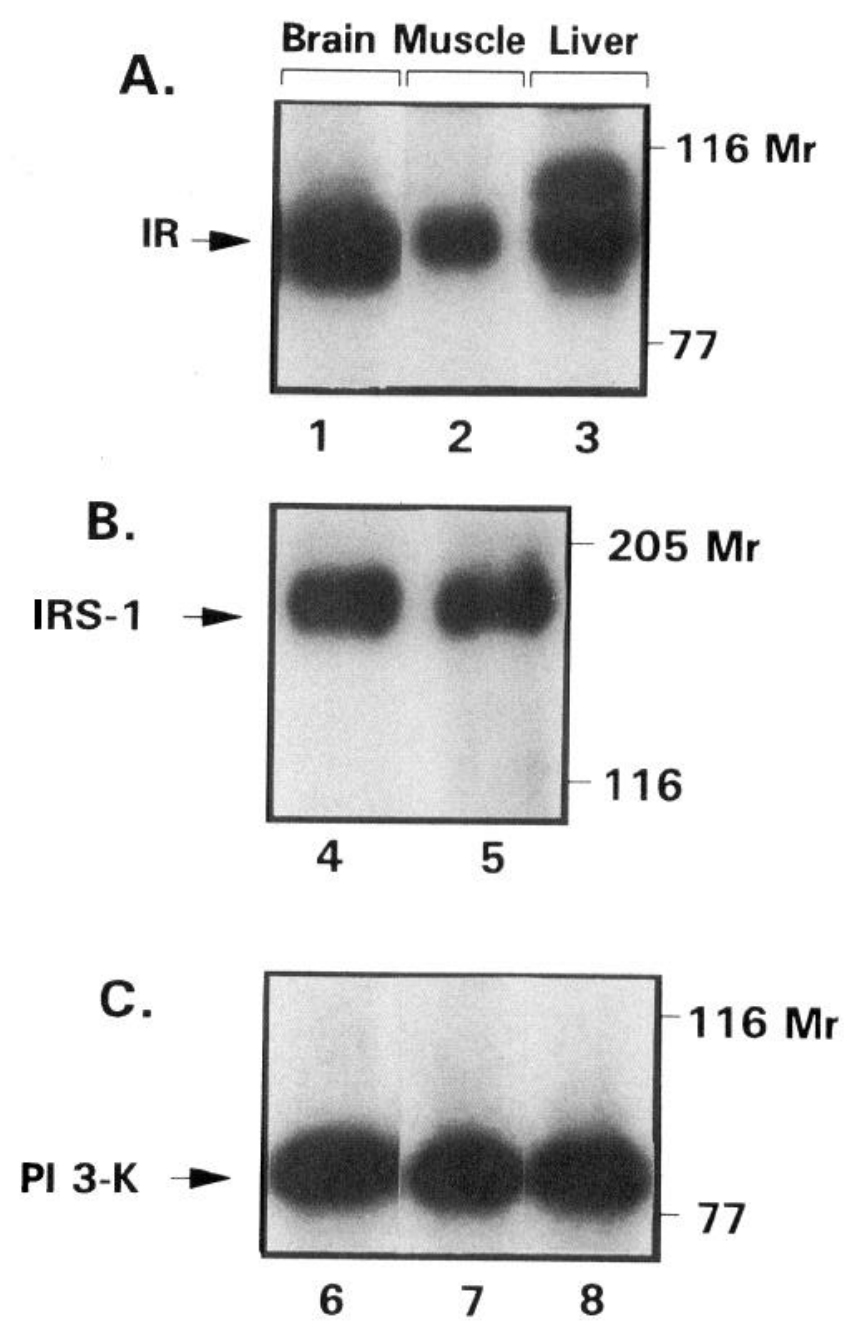

Figure 1. Western blot analysis of insulin receptor $\beta$-subunit in antiinsulin receptor antibody (IR-CT) immunoprecipitates $(A)$, IRS-1 protein in anti-NT-IRS-1 antibody immunoprecipitates $(B)$, and PI-3 kinase ( $85 \mathrm{kDa}$ subunit) in anti-PI-3 kinase antiserum immunoprecipitates $(C)$. Proteins from rat brain, skeletal muscle and liver were extracted as described in Materials and Methods. After centrifugation, aliquots containing the same amount of proteins were incubated with anti-insulin receptor (IR-CT), anti-NT-IRS-1 or anti-PI-3 kinase antibodies and protein A-Sepharose. Immunoprecipitated proteins were analyzed by Western blotting with either anti-insulin receptor antibodies (IRCT), anti-CT-IRS- 1 antibodies, or anti-PI-3 kinase antiserum and ${ }^{125}$ Iprotein $A$ and subjected to autoradiography. Lanes 1, 4, and 6, brain; lanes 2, 5, and 7, muscle; lanes 3 and 8 , liver. $I R$, insulin receptor; $P I$ $3-K$, PI-3 kinase.

affinity-purified antibody with different concentrations of the synthetic peptide used to raise the antibody; (2) liquid phase adsorption of the anti-NT-IRS-1 peptide affinity-purified antibody with different concentrations of the synthetic CT-IRS-1 peptide (Folli et al., 1993), and synthetic Pep-80 peptide (Rothenberg et al., 1991); (3) omission of primary antisera or their substitution with normal serum; and (4) omission of second-layer biotinylated antibodies or avidin-biotin-peroxidase complex in the $\mathrm{ABC}$ procedure.

\section{Results}

\section{Biochemistry}

In order to examine the relative level of expression of insulin receptor, IRS-1, and PI-3 kinase in rat brain as compared to two classical targets of the metabolic actions of insulin, that is, skeletal muscle and liver, immunoprecipitation was followed 
by Western blotting employing antibodies directed against the $\beta$-subunit of the insulin receptor (Fig. $1 A$ ), the IRS-1 protein (Fig. $1 B$ ), and the $85 \mathrm{kDa}$ subunit of PI-3 kinase (Fig. $1 C$ ). This experiment suggests that all three proteins are present in adult rat CNS at similar concentrations as compared to muscle and liver. Western blot analysis of tyrosyl-phosphorylated proteins in anti-insulin receptor $\beta$-subunit immunoprecipitates from rat brain and muscle extracts confirmed that following intraportal insulin administration, there was no increase in the phosphorylation of the insulin receptor or IRS- 1 in the brain, while there was a clear stimulation of the tyrosyl-phosphorylation of these proteins in skeletal muscle (data not shown).

\section{Immunocytochemistry}

General considerations on IRS-1 immunolocalization

IRS-1 immunoreactivity was detected in most nerve cells throughout the CNS, but not in all neurons of the brain and spinal cord. IRS-1 immunostaining was usually restricted to the neuronal perikarya (Figs. 2-4). However, in certain brain regions, such as the cerebellar cortex and many brainstem nuclei, considerable amounts of reaction product were observed in the initial portion of the primary dendrites. This was particularly true for large neurons, in which immunostaining was often stronger in the dendrites than in the cell body (Fig. 4.A). Although quantitative evaluations could not be performed, the staining intensity was different between the various IRS-1-positive neuronal populations; for example, it was consistently high in hippocampal neurons and very faint in magnocellular supraoptic nerve cells.

Except the ependymal cells lining the third ventricle and cells of the choroid plexus, neurons were the only cells in the brain and spinal cord expressing immunoreactive IRS-1. Glial cells and other non-neuronal elements had no detectable IRS-1 protein. The specific labeling of neurons by the anti-IRS-1 antiserum was completely abolished after liquid phase adsorption with its corresponding synthetic peptide.

\section{Distribution of IRS-1 immunoreactivity in the rat CNS}

Olfactory bulb. Neuronal cell bodies were usually immunonegative in the olfactory bulb. Faint IRS-1 staining was occasionally observed in the mitral cell perikarya and in neurons of the anterior olfactory nucleus. In the glomerular layer a fine punctate reaction was present, likely due to the olfactory nerve terminals.

Cerebral cortex. IRS-1 immunoreactivity was detected in all the cortical areas, but it was particularly prominent in the piriform cortex. Immunoreactive nerve cells were found in all cortical layers, and there was no obvious difference between layers in the density of positive cells (Fig. 2C). The reaction product was generally restricted to the cell bodies of the pyramidal neurons but, occasionally, it was also found in the initial part of their apical dendrites.

Hippocampus. Strong IRS-1 immunoreactivity was observed in the hippocampus (Fig. $2 A, B$ ). This staining was localized within the cell bodies of the Ammon's horn pyramidal neurons (in CA1-CA3 fields) and the dentate gyrus granules (Fig. 2A). IRS-1 immunoreactivity was also present in cell bodies of scattered neurons located in the polymorph layer, which likely correspond to the basket cells, and interneurons of the stratum radiatum (Fig. $2 B$ ). Therefore, nearly all of the different types of hippocampal neurons showed expression of IRS-1.

Hypothalamus, thalamus, and epithalamus. Striking IRS-1 immunoreactivity was obscrved in the hypothalamic and thalamic regions surrounding the third ventricle and the habenular nuclei. In many hypothalamic nerve cells the staining was very intense (Fig. 3A). In contrast, IRS-1 immunoreactivity was at the limit of detectability or totally absent in the supraoptic and paraventricular nuclei.

Basal ganglia. A fine granular reaction was consistently detected in neurons of the basal ganglia.

Cerebellum. In the cerebellar cortex immunoreactivity was restricted to the Purkinje neuron layer, with a characteristic pattern of distribution (Fig. $3 B, C$ ). Both in parasagittal and coronal sections, clusters of IRS-1-positive and IRS-1-negative Purkinje neurons alternated regularly with each other (Fig. $3 B$ ), with the immunonegative cells prevailing over those stained by the anti-IRS- 1 antiserum. The latter showed a dense, granular staining of their cell body, which was also often detectable in the main dendrites (Fig. 3C). IRS-1 immunostaining was also associated with neurons located in the deep cerebellar nuclei.

Brainstem. IRS-1 immunostaining was present in a wide number of brainstem nuclei (Fig. $4 A$ ) including the solitary, cochlear, and trapezoid body nuclei and the reticular formation. Very faint staining was observed in sensory neurons of the trigeminal nucleus.

Spinal cord. Scattered IRS-1-immunoreactive nerve cells were observed throughout the spinal gray matter at all segmental levels investigated. Their main location was in laminae V-VI and $\mathrm{X}$ (Fig. 4B). However, immunoreactive neurons were occasionally detected in the dorsal horn (laminae I-III) and in laminae VII-IX of the ventral horn. Motoneurons accounted for most of the immunoreactive cells in this area of the spinal cord.

Retina. IRS-1 immunoreactivity was observed in the ganglion cell layer and, to a lesser extent, in the inner nuclear layer. Within

\footnotetext{
Figure 2. IRS-1 immunoreactivity in the brain. Strong IRS-1 staining is visible in neuronal perikarya of the hippocampus $(A, B)$ and cerebral cortex $(C)$, while dendrites are usually frec of label. Most of the cclls in the dentate gyrus granular layer $(A, g l)$, as well as pyramidal cells in the Ammon's horn $(A, B, c a)$, are immunoreactive; some immunopositive cells are also visible in the polymorph layer $(A, p o)$ and in the stratum radiatum $(B, s r$, arrows). IRS-1-immunoreactive pyramidal neurons (frontal cortex, $C$ ) occur in all cortical layers. Magnification: $A, 170 \times ; B$ and $C, 270 \times$.

Figure 3. IRS-1 immunoreactivity in the brain. $A$, Strong IRS-1 staining in the cell bodies and processes of most (but not all) neurons in the ventral hypothalamus. $B$ and $C$, In the cerebellar cortex, the immunoreactivity is associated with clusters of Purkinje neurons $(B, a r r o w s)$. These clusters are separated by many neurons of the same type that appear immunonegative $(C$, arrowheads); the granular layer $(g l)$ appears free of label. Magnification: $A, 340 \times ; B, 180 \times ; C, 460 \times$.

Figure 4. IRS-1 immunorcactivity in the brainstem $(A)$, spinal cord $(B)$, and retina $(C)$. In the brainstem $(A)$, IRS-1 staining is preferentially localized in the cell bodies and dendrites of large/medium sized neurons; frequently it is confined in the proximal part of large dendrites (inset). $B$, Many IRS-1-positive neurons are visible in lamina $\mathrm{X}$ of the spinal cord gray matter, around the central canal (asterisk). In the retina $(C)$, immunoreactivity is mainly associated with large-sized retinal ganglion cells within the ganglion cell layer ( $\mathrm{gcl}$ ). A punctate reaction is also visible in the inner plexiform layer (ipl). Magnification: $A, 340 \times($ inset, $510 \times) ; B, 450 \times ; C, 1650 \times$.
} 

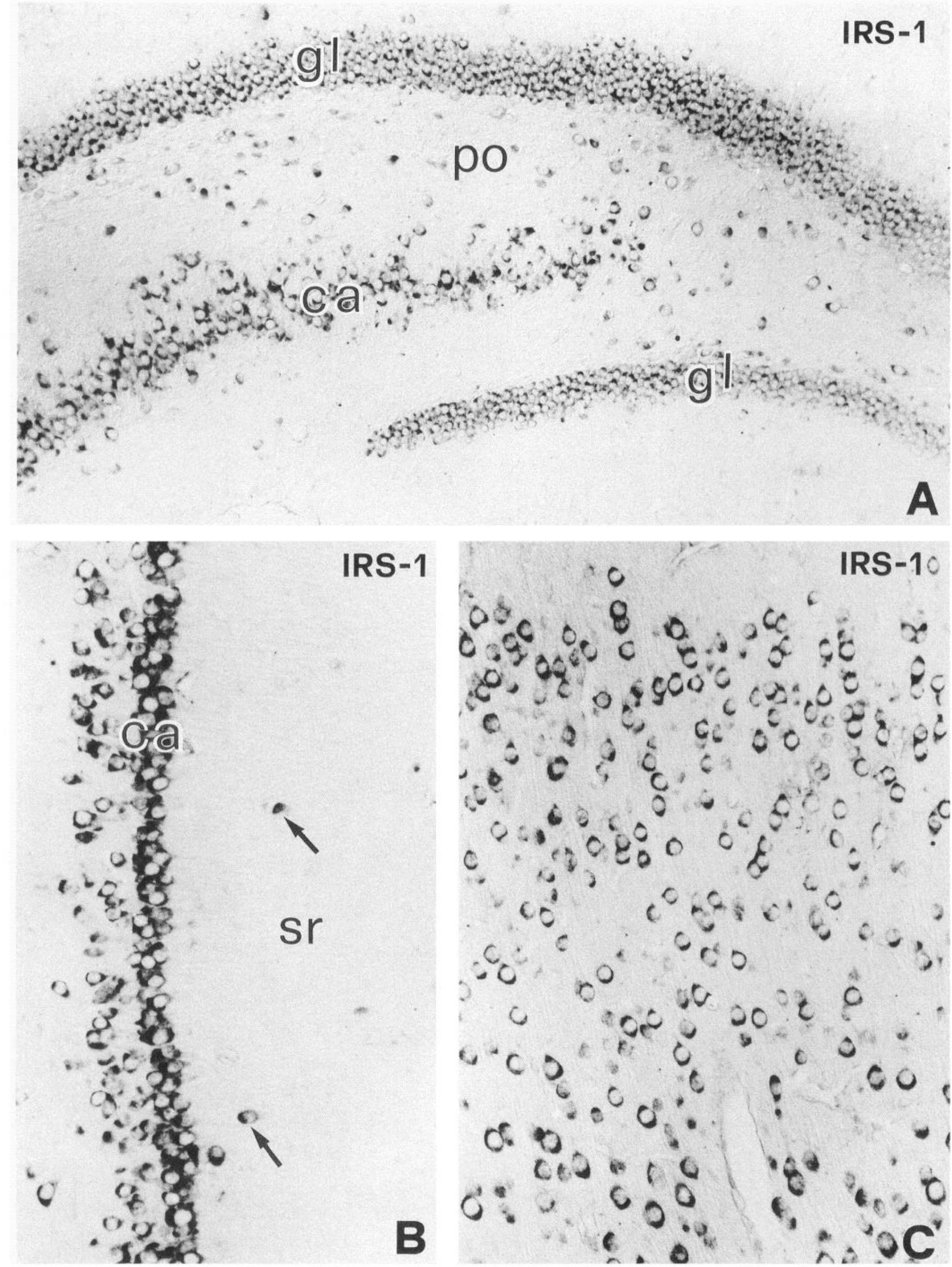

IRS-1

10 IRS-10

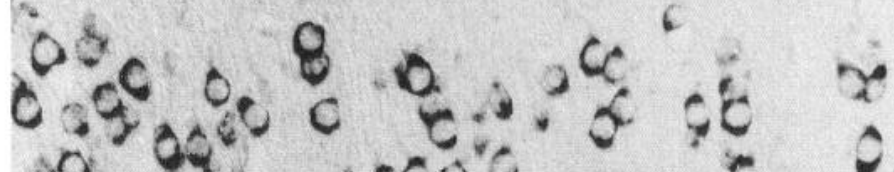

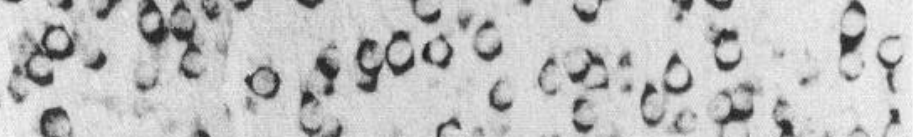

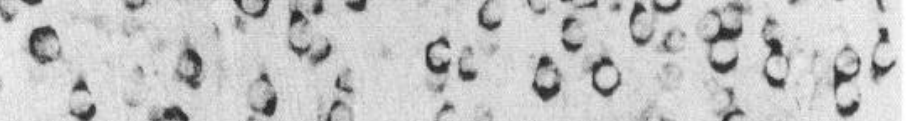

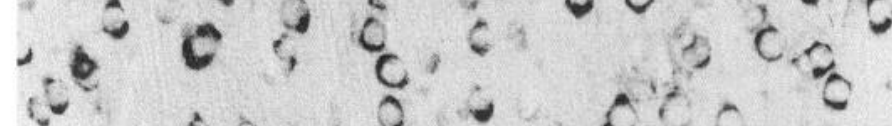

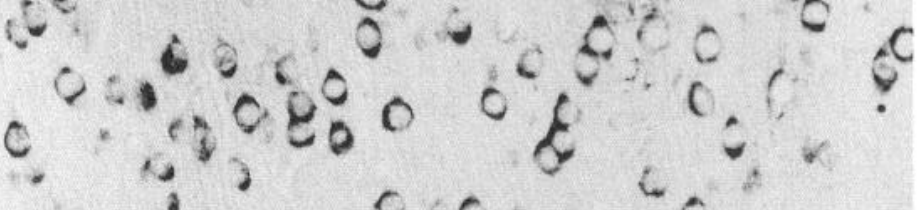

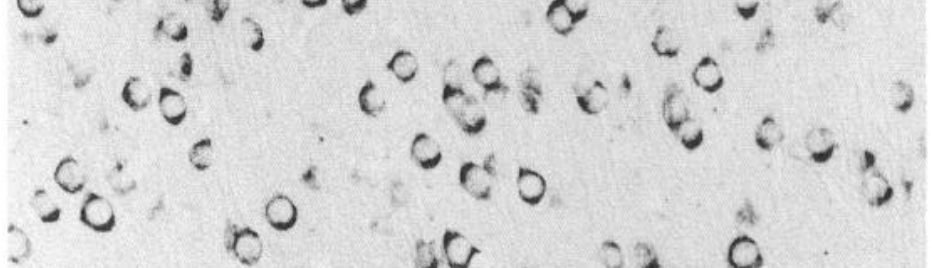

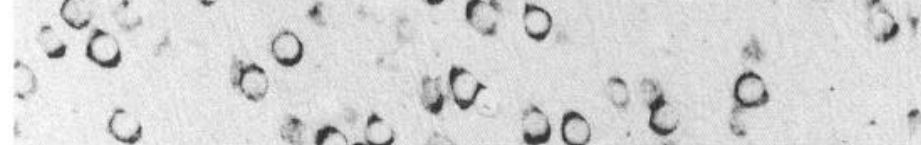

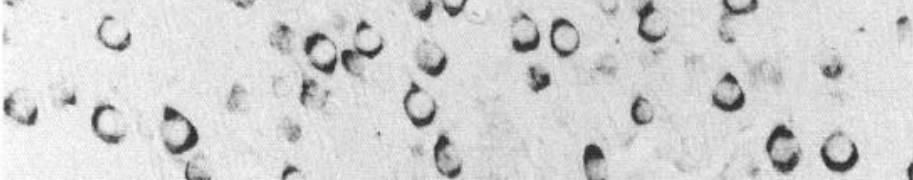

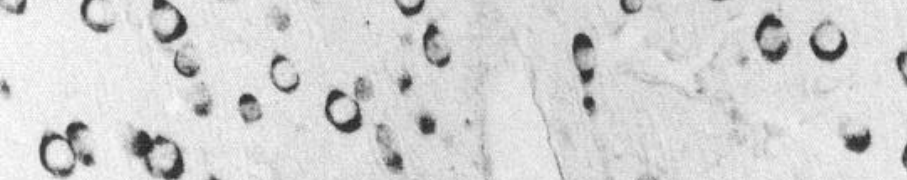

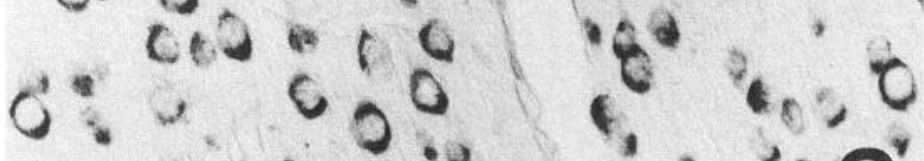
3 c. $0^{2}+{ }^{2} \mathrm{OC}^{2}$ 


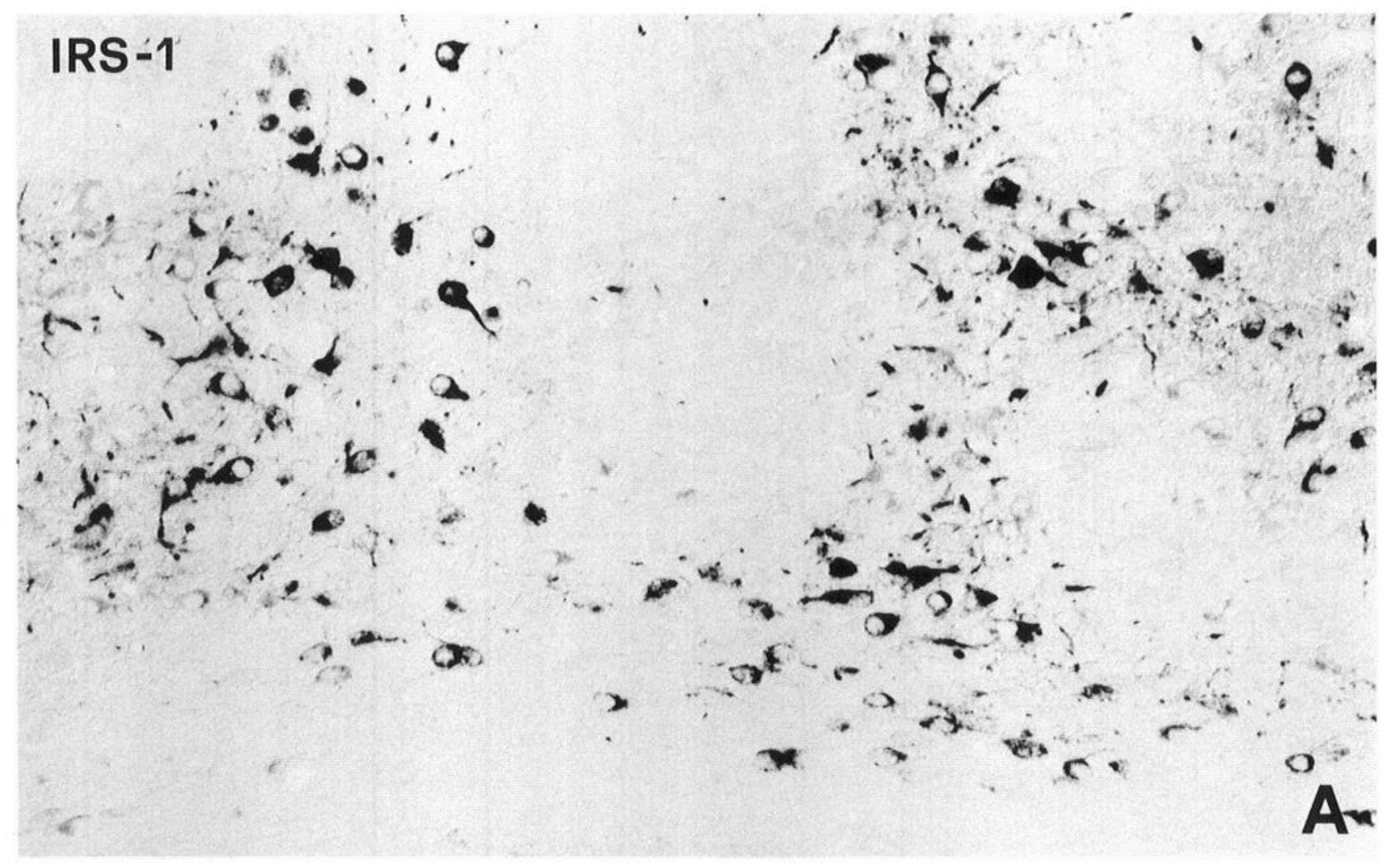

\section{IRS -1}

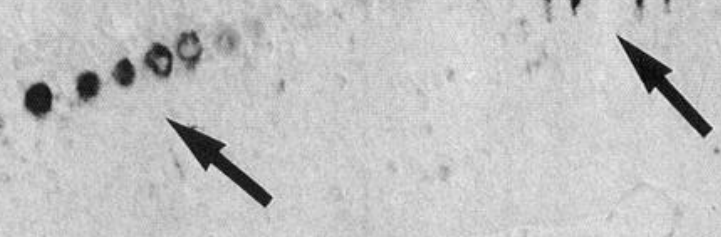

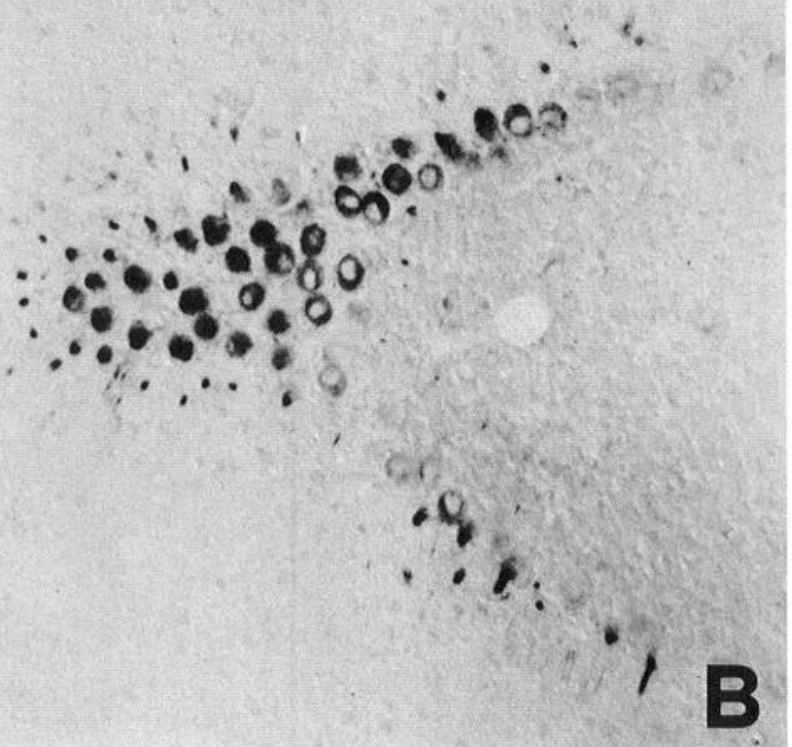

IRS -1

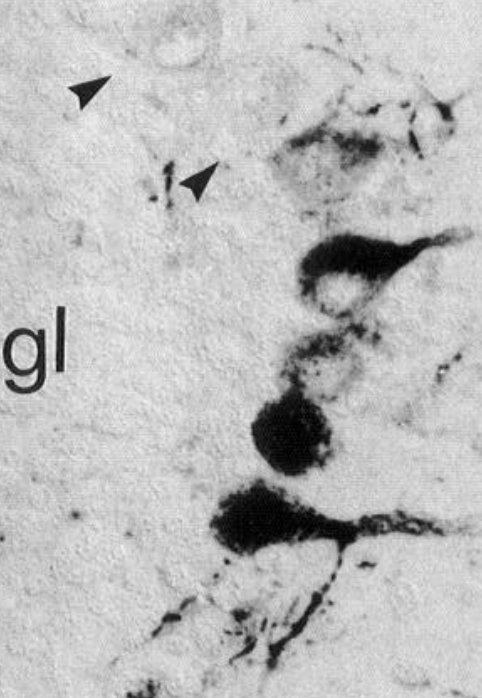




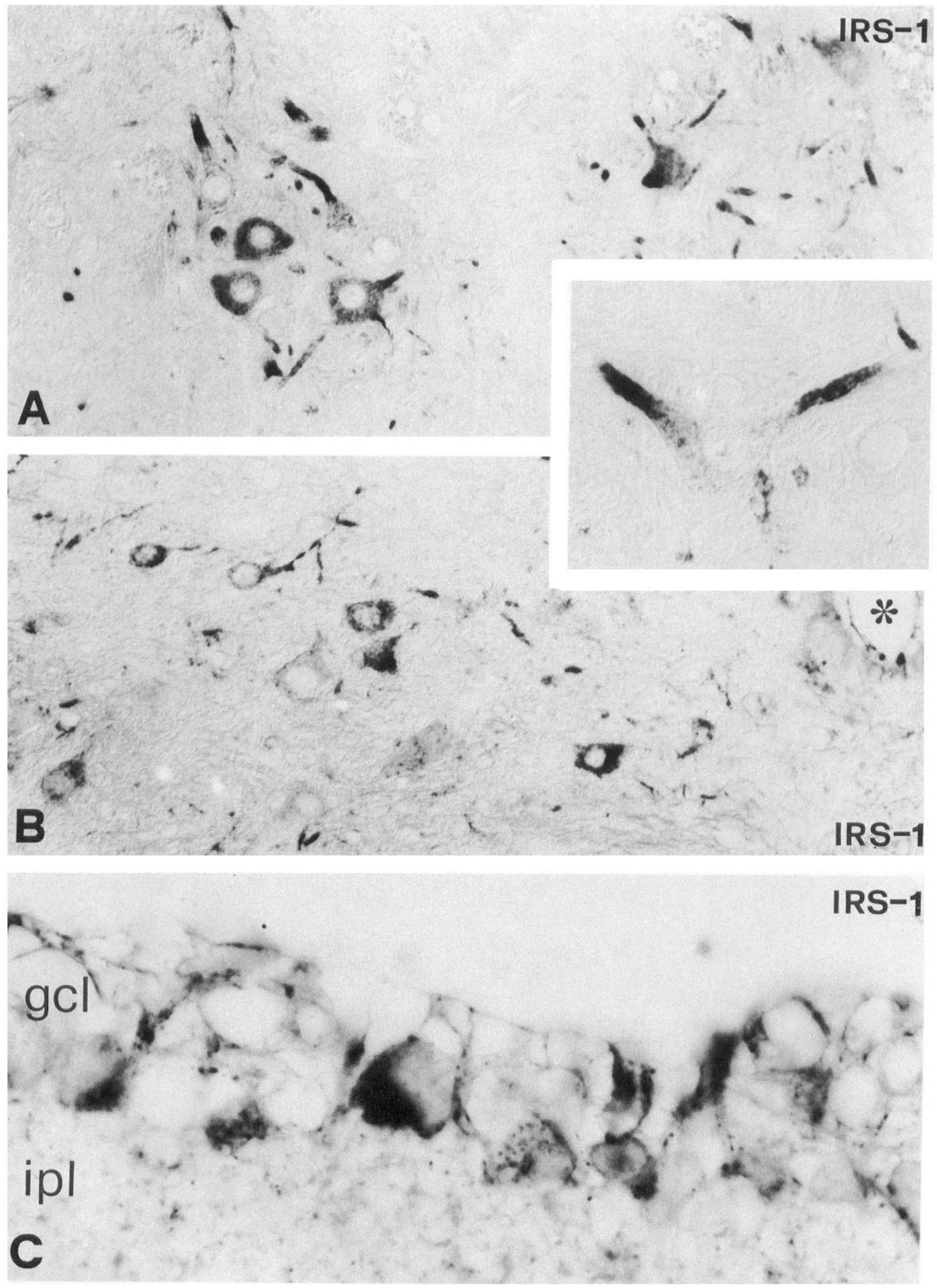




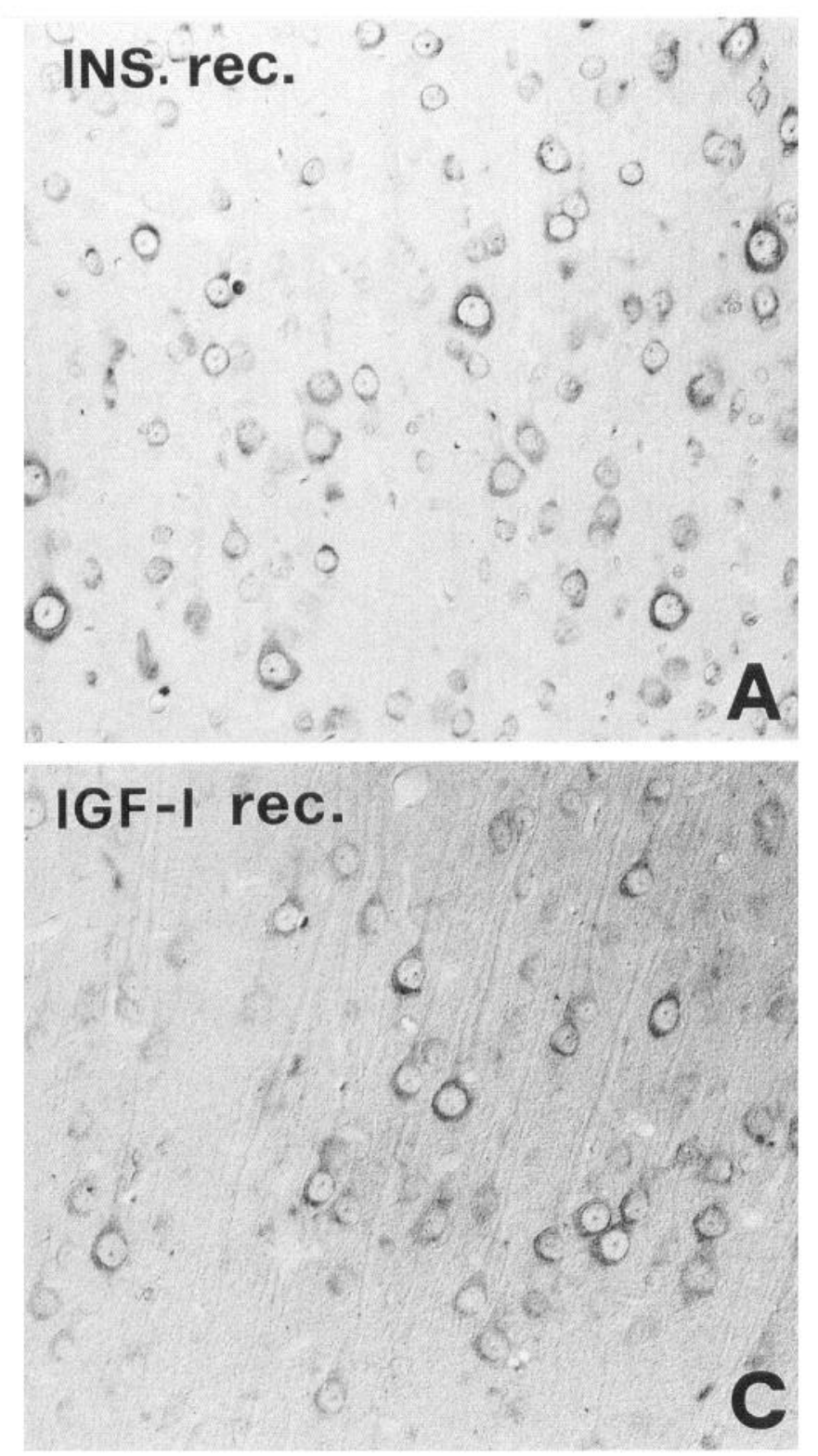

\section{$P I-3 k i n a s e$}

(9)

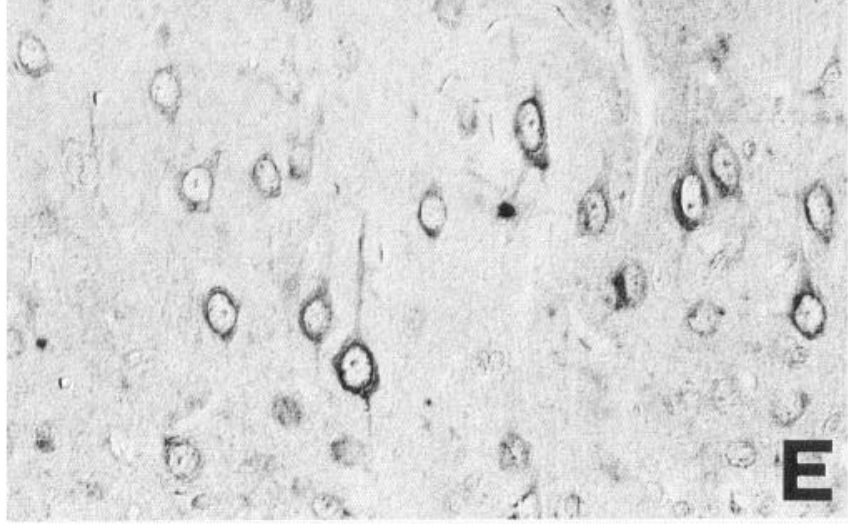

(8) 93.
INS. rec.

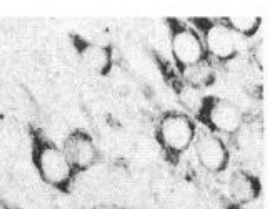

\section{IGF-I rec:}

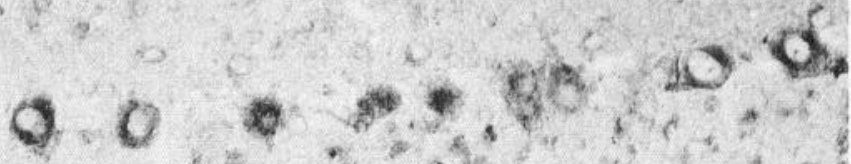

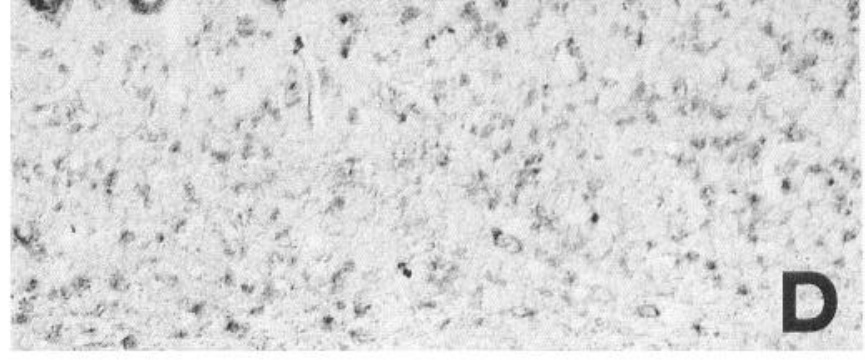

\section{$\mathrm{PI}-3$ kinase}

\section{A}

$000 \% 900100.0$

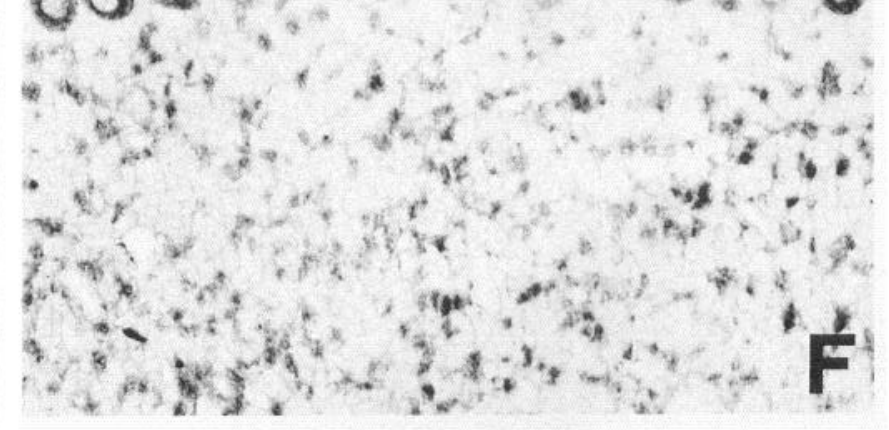


the former, staining was associated with the cell bodies of retinal ganglion cells, mainly of large diameter (Fig. 4C). In the inner nuclear layer a faint IRS-1 positivity was present in some amacrine and bipolar cells.

\section{Distribution of insulin receptor, IGF-I receptor, and PI-3 kinase in the rat $C N S$}

In most of the areas investigated, a good correlation between the distribution of IRS- 1 and insulin receptor immunoreactivities was found, with almost overlapping patterns within the cerebral cortex, hippocampus, and brainstem (Fig. 5). Only minor differences in the distribution of insulin receptor immunostaining were observed, such as, for example, in the cerebral cortex, where staining for the insulin receptor was particularly evident within layer IV and the hippocampus, where insulin receptor immunoreactivity was very weak in the dentate gyrus. In other regions of the brain, on the other hand, significant differences in the localization of IRS-1 and insulin receptor immunoreactivities were observed. The latter was very strong in the olfactory bulb and the hypothalamic supraoptic nucleus, which, as described above, contained little or no detectable IRS1. In the thalamus, hypothalamic nuclei and septal nuclei, insulin receptor immunostaining was preferentially associated with axons and terminals, rather than with the neuronal perikarya. In the cerebellar cortex, Purkinje neurons were only weakly reactive after incubation with anti-insulin receptor antibodies.

The distributions of IGF-I receptor and PI-3 kinase immunoreactivities were very similar and overlapped that of IRS-1 in the cerebral cortex (Fig. 5C,E) and hippocampus. As for the insulin receptor, staining was particularly prominent in cortical layer IV. In the hippocampus, IGF1-receptor immunoreactivity was stronger in the Ammon's horn than in the dentate gyrus. In the cerebellar cortex, IGF-I receptor and PI-3 kinase immunoreactivities were detected in almost all Purkinje neurons, without the characteristic pattern observed after incubation with the anti-IRS-1 antiserum (Fig. 5D,F). Moreover, weak IGF-I receptor staining was detected in the granular layer (Fig. $5 D$ ). Differences in the pattern of distribution of IGF-I receptor, PI-3 kinase and IRS-1 immunoreactivities were not obviously apparent in the brainstem and spinal cord. These results are summarized in Table 1.

\section{Discussion}

Protein tyrosine kinases can be subdivided into two large families: the transmembrane growth factor receptors family and the cytosolic nonreceptor family. These proteins are commonly regarded as fundamental components of mitogenic pathways and are highly expressed in non-nervous tissues where they appear to play a crucial role in the control of cell growth and metabolism in both physiologic and pathologic states (Cantley et al., 1991). Nevertheless, many observations indicate the presence of substantial amount of tyrosine kinase activity in the CNS, which is typically composed of nonproliferating cells (Nairn et al., 1985; Hunter, 1987). Using the biochemical and immunocytochemical approach, this study describes the presence and cel-

\begin{tabular}{|c|c|c|c|c|}
\hline $\begin{array}{l}\text { CNS } \\
\text { regions/nuclei }\end{array}$ & IRS-1 & $\begin{array}{l}\text { Insulin } \\
\text { receptor }\end{array}$ & $\begin{array}{l}\text { IGF-I } \\
\text { receptor }\end{array}$ & $\begin{array}{l}\text { PI-3 } \\
\text { kinase }\end{array}$ \\
\hline Olfactory bulb & No & Yes & No & No \\
\hline Cerebral cortex ${ }^{a}$ & Yes & Yes & Yes & Yes \\
\hline $\begin{array}{l}\text { Hypothalamus }{ }^{b} \text { thala- } \\
\text { mus } \\
\text { sON/PVN magnocellu- }\end{array}$ & Yes & Yes $^{c}$ & No & Yes \\
\hline lar neurons & No & No & Yes & Yes \\
\hline $\begin{array}{l}\text { Basal ganglia } \\
\text { Cerebellar cortex }\end{array}$ & Yes & Yes & Yes & Yes \\
\hline Purkinje cell layer & Yes & Yes $^{d}$ & Yes $^{d}$ & Yes $^{d}$ \\
\hline Granule cell layer & No & No & Yes & Yes \\
\hline Deep cerebellar nuclei & Yes & Yes & No & Yes \\
\hline Brainstem $^{e}$ & Yes & Yes & Yes & Yes \\
\hline $\begin{array}{l}\text { Mesencephalic trigemi- } \\
\text { nal nucleus }\end{array}$ & No & No & Yes & Yes \\
\hline Spinal cord & Yes & Yes & Yes & Yes \\
\hline Retina & Yes & ND & ND & Yes \\
\hline
\end{tabular}

$\overline{\text { Yes, presence of immunoreactivity; no, absence of immunoreactivity or very weak }}$ immunolabeling; ND, not done. IRS-1, insulin receptor substrate-1; IGF-I, insulin-like growth factor I; PI-3 kinase, phosphatidylinositol-3 kinase; SON, supraoptic nucleus; PVN, paraventricular nucleus.

${ }^{a}$ Differences were observed in layer IV (see text)

${ }^{b}$ Other than SON/PVN magnocellular neurons.

- Immunostaining was associated with fibers rather than cell bodies.

${ }^{d}$ Staining was observed in all Purkinje neurons.

- Other than the mesencephalic trigeminal nucleus.

lular localization of IRS- 1 and PI-3 kinase in the rat brain and spinal cord and confirms the existence of insulin and IGF-I receptors in the CNS (Posner et al., 1974; Havrankova et al., 1978; Gammeltoft et al., 1985, 1990; Hill et al., 1986; Bohannon et al., 1988; Lesniak et al., 1988; Ocrant et al., 1988; Unger et al., 1989, 1991a,b; Moss et al., 1990; King and Baskin, 1991). The unique nature of the distribution of IRS- 1 in the rat CNS and the possible functional implications of our findings, which suggest that several neuronal populations are capable of responding in vivo to insulin, IGF-I, and, possibly, other growth factor stimulation, deserve further consideration.

Our biochemical and immunocytochemical results demonstrate that IRS- 1 is widely distributed in the rat brain and spinal cord. In particular IRS-1 protein expression data are in agreement with the results obtained from quantitative PCR of IRS-1 mRNA from human fetal tissues (Araki et al., 1993). High levels of immunoreactivity are found in the cerebral and cerebellar cortices, the hippocampus and several brainstem nuclei. It is of interest that within some of these areas, such as the cerebral cortex, IRS-1 seems to be detectable, although at different levels, in virtually all neurons. Conversely, in other regions of the CNS, such as the cerebellum, the molecule is clearly limitcd to certain neuronal subpopulations. The nerve cells that are positive for

\footnotetext{
Figure 5. Immunoreactivity for the insulin $(A, B)$ and IGF-I $(C, D)$ receptors, and PI-3 kinase $(E, F)$ in some of the brain regions that are highly immunoreactive for IRS-1. In the cerebral cortex $(A, C, E)$, immunoreactivity to the three antigens is visible in the cytoplasm of pyramidal neurons. In the hippocampus $(B)$, a strong staining for insulin receptor is present in the cell bodies of the Ammon's horn pyramidal neurons. In the cerebellar cortex, the perikarya of Purkinje neurons and granule cells are immunoreactive for IGF-I $(D)$ and PI-3 kinase $(F)$. Magnification: $A, C, D, F, 280 \times$; $B, 235 \times ; E, 335 \times$.
} 
IRS-1-immunoreactive material, however, are involved with different functions and are known to be neurochemically heterogeneous (see, e.g., Brodal, 1993).

Previous studies have mapped the distribution of insulin and IGF-I receptors in the rat brain using immunocytochemical and/ or autoradiographic techniques (Posner et al., 1974; Havrankova et al., 1978; Gammeltoft et al., 1985, 1990; Hill et al., 1986; Bohannon et al., 1988; King and Baskin, 1991; Lesniak et al., 1988; Ocrant et al., 1988; Unger et al., 1989, 1991a,b; Moss et al., 1990). Therefore, we decided to restrict our analysis to the areas of the CNS that were immunoreactive for IRS-1, rather than performing a complete map of these antigens; likewise, we used the same approach to analyze the distribution of PI-3 kinase, although no data are available in the literature concerning the localization of this molccule in the rat ncrvous system. This decision was dictated by the consideration that our main goal was to correlate the distribution of the above antigens with that of IRS-1. Our results on the distribution of these receptors are in substantial agreement with the studies quoted above and indicate that in a wide number of neurons from different regions of the rat brain there is a good correlation between the distribution of insulin and IGF-I receptors and that of IRS-1. In addition, we have identified IRS-1-immunoreactive nerve cells that express either the insulin or IGF-I receptors and PI-3 kinase and thus appear to be endowed with the major components of the insulin/IGF-I intracellular signaling pathway.

Recently, the crucial effects of insulin-like growth factors in the regulation of embryonic and postnatal growth have been demonstrated in mouse embryos carrying null mutations of the genes encoding IGF-I, IGF-II, and IGF-I receptor (Baker et al., 1993). While the concept that neurons require functionally active cellular signaling machinery to respond to growth factors during development and early postnatal life appears to be an obvious consequence of the growth factor paradigm, the functional significance of most neurons within the adult CNS, which are endowed with some of the molecular structures to respond to the growth factors of the insulin/IGF-I family is more difficult to explain. Although the source of brain insulin is still under debate, a growing body of evidence suggests that brain insulin comes from peripheral uptake, through a receptor-mediated active transport across the blood-brain barrier or via the circumventricular organs (see Unger et al., 1991a, for review). On the other hand, IGF-I and IGF-II have been shown to be produced locally, although at different developmental stages, and receptors for both molecules are present in the adult rat CNS (Gammeltoft et al., 1985, 1990). Thus, a major role for IRS-1 and its associated signaling proteins may be as mediators of a paracrine response to IGF-I or IGF-II, although the exact nature of such a response is still unclear.

Our immunoprecipitation and Western blotting experiments in the brain show that acute insulin administration into the portal vein does not lead to tyrosyl phosphorylation of either the insulin receptor $\beta$-subunit or IRS-1. These data are in agreement with the notion that insulin levels in the cerebrospinal fluid do not change after a meal and that persistent peripheral hyperinsulinemia is necessary to alter the brain/plasma ratio of the hormone (Schwartz et al., 1990, 1992). Whatever the source and mechanisms through which insulin gains access to neurons, its main effect in vivo seems to consist in the neurochemical regulation of feeding behavior (Lauteriot et al., 1990).

The wide distribution of IRS- 1 and insulin and IGF-I recep- tors in the CNS, as demonstrated in this and other studies (see above), indicates that neurons that are likely to respond in vivo to growth factors of the insulin/IGF-I family are not limited to the brain areas concerned with central autonomic regulation of food intake. Therefore, additional roles for insulin/IGF-I in the adult brain can be postulated.

In vitro studies have proved that cultured neurons and neuroblastoma cell lines are capable of responding to insulin and IGF-I in terms of cell growth and metabolic effects in a manner similar to non-neural cells (Shemer et al., 1987a,b; Heidenreich et al., 1991; Unger et al., 1991a). Other experiments have shown effects on neurite outgrowth (Ang et al., 1993) and synaptogenesis (Puro and Agardh, 1984). All of these actions result in morphologic remodeling of neural connections, which, under physiologic conditions, are known to occur only in a few arcas of the intact adult CNS (see, e.g., Theodosis and Poulain, 1993). It has been recently reported that the coadministration of IGF-I and glutamate into the cerebellar cortex and the deep cerebellar nuclei greatly depresses the release of GABA, which normally follows a glutamate pulse and that electrical stimulation of the inferior olivary complex significantly raises IGF-I levels in the cerebellar cortex (Castro-Alamancos and Torres-Aleman, 1993). More recent findings suggest that the responsiveness of cerebellar granule cells to glutamate in vivo might be epigenetically regulated by IGF-I (Calissano et al., 1993). Taken together these data indicate a role for IGF-I in modulating the neural activity within certain areas of the mature CNS.

From our work it also appears that there is heterogeneous expression of IRS- 1 in the Purkinje cells of the cerebellum that follows a sagittal banding. By contrast, all of these neurons are immunoreactive for insulin receptors, IGF-I receptors and PI-3 kinase. A possible explanation for this finding is that IRS-1 is removed from the cell when the latter is not functionally active and therefore the molecule is no longer required. In keeping with this assumption, electrophysiological and anatomical evidence has shown that the olivocerebellar and the corticonuclear pathways are arranged into sagittal projection zones and are activated in sagittal bands (Armstrong et al., 1982; Chan-Palay et al., 1982). Alternatively, it is also possible that in neurons that do not contain IRS-1, the enzyme PI-3 kinase associates directly with the insulin and IGF-I receptors or with other adaptor molecules as demonstrated in other cell types (Backer et al., 1992b; Lapetina et al., 1992; Yonezawa et al., 1992).

Finally, it is important to emphasize that from our results a number of neurons that express IRS- 1 do not appear to contain either insulin or IGF-I receptors. A possible explanation for this finding is that IRS-1 may be an intracellular substrate for receptors belonging to different families of growth factors. Although such a possibility has already been demonstrated in hematopoietic cell lines, in which IL-4 has been shown to use IRS-1, or an IRS-1-like molecule, as an intracellular substrate (Wang et al., 1993a,b), it appears that a growth factor dependent tyrosine-phosphorylated $100 \mathrm{kDa}$ protein other than IRS-1 associates with the PI-3 kinase $\mathrm{SH} 2$ domain following activation of the NGF and FGF receptors in the brain (Chao, 1992; Saltiel and Ohmici, 1993). In keeping with the above results, we observed in this study some neurons, which were PI-3 kinase immunoreactive but did not express IRS-1.

It is also of interest that both SHPTP2 and GRB2, which are highly expressed in the mammalian CNS and in other tissues (Freeman et al., 1992; Lowenstein et al., 1992), bind to specific phosphorylated YIDL and YVNI of IRS-1, different from the 
motifs that bind to PI-3 kinase (Sun et al., 1993). Thus, it is tempting to hypothesize that intracellular signaling pathways activated by phosphorylated IRS- 1 may be different between the various subpopulations of immunoreactive neurons.

In conclusion, this study demonstrates that a large number of neurons in the adult CNS are endowed with many of the early components of the signal transduction pathway for receptor tyrosine kinases of the insulin/IGF-I growth factor family, although in a few areas of the brain the expression of IRS-1 and PI-3 kinase does not parallel the distribution of the insulin and/ or IGF-I receptors. These results highlight the importance of correctly understanding the functional significance of receptor tyrosine kinases in cells that are postmitotic and undergoing terminal differentiation. Protein tyrosine kinases have been traditionally regarded as cell-transforming agents, but a growing body of evidence suggests that in the adult brain they are more likely to be involved in sculpting and maintaining the synaptic circuitry and architecture of the mature nervous system (Chao, 1992; Grant et al., 1992; Saltiel and Ohmici, 1993).

\section{References}

Ang LC, Bhaumick B, Jurlink BHJ (1993) Neurite promoting activity of insulin, insulin-like growth factor I and nerve growth factor on spinal motor neurons is astrocyte dependent. Dev Brain Res 74:8388.

Araki E, Sun X-J, Haag BL, Chuang L-M, Zhang Y, Yang-Feng TL, White MF, Kahn CR (1993) Human skeletal muscle insulin receptor substrate-1. Characterization of the cDNA, gene, and chromosomal localization. Diabetes 42:1041-1054.

Armstrong DM, Campbell NC, Edgley SA, Schild RF, Trott JR (1982) Investigations of the olivocerebellar and spinocerebellar pathways. In: The cerebellum: new vistas (Palay SL, Chan-Palay V, eds), pp 195-232. Berlin: Springer.

Backer JM, Myers MG Jr, Shoelson SE, Chin DJ, Sun XJ, Miralpeix M, Hu P, Margolis B, Skolnik EY, Schlessinger J, White MF (1992a) Phosphatidylinositol 3-kinase is activated by association with IRS-1 during insulin stimulation. EMBO J 9:3469-3479.

Backer JM, Schroeder GG, Kahn CR, Myers MG Jr, Wilden PA, Cahill DA, White MF (1992b) Insulin stimulation of phosphatidylinositol 3-kinase activity maps to insulin receptor regions required for endogenous substrate phosphorylation. J Biol Chem 267:1367-1374.

Baker J, Liu J-P, Robertson EJ, Efstradiatis A (1993) Role of insulinlike growth factor in embryonic and postnatal growth. Cell 76:73-82.

Bohannon NJ, Corp ES, Wilcox BJ, Figlewicz DP, Dorsa DM, Baskin DG (1988) Localization of binding sites for insulin-like growth factor-I (IGF-I) in the rat brain by quantitative autoradiography. Brain Res 444:205-213.

Bradford MM (1976) A rapid and sensitive method for the quantitation of microgram quantities of protein utilizing the principle of protein dye binding. Anal Biochem 72:248-254.

Brodal P (1993) The central nervous system: structure and function. London: Oxford UP.

Calissano P, Ciotti MT, Battistini L, Zona C, Angelini A, Merlo D, Mercanti D (1993) Recombinant human insulin-like growth factor I exerts a trophic action and confers glutamate sensitivity on glutamate-resistant cerebellar granule cells. Proc Natl Acad Sci USA 90: 8752-8756.

Cantley LC, Auger KR, Carpenter CL, Duckworth B, Graziani A, Kapeller R, Soltoff S (1991) Oncogenes and signal transduction. Cell 64:281-302.

Castro-Alamancos MA, Torres-Aleman I (1993) Long-term depression of glutamate-induced $\gamma$-aminobutyric acid release in cerebellum by insulin-like growth factor I. Proc Natl Acad Sci USA 90:73867390.

Chan-Palay V, Palay SL, Wu J-Y (1982) Sagittal cerebellar microbands of taurine neurons: immunocytochemical demonstration by using antibodies against the taurine synthesizing enzyme cysteine sulfinic acid decarboxylase. Proc Natl Acad Sci USA 79:4221-4225.

Chao MV (1992) Neurotrophin receptors: a window into neuronal differentiation. Neuron 9:583-593.

Cheatham B, Shoelson SE, Yamada K, Goncalves E, Kahn R (1993)
Substitution of the $e r b \mathrm{~B}-2$ oncoprotein transmembrane domain activates the insulin receptor and modulates the action of insulin and insulin-receptor substrate 1. Proc Natl Acad Sci USA 90:7336-7340.

Cohen B, Liu Y, Druker B, Roberts TM, Schaffhausen BS (1990) Characterization of pp85, a target of oncogenes and growth factor receptors. Mol Cell Biol 10:2909-2915.

Endemann G, Yonezawa KK, Roth R (1990) Phosphatidylinositol kinase or an associated protein is a substrate for the insulin receptor tyrosine kinase. J Biol Chem 265:396-400.

Folli F, Saad MJA, Baker JM, Kahn CR (1992) Insulin stimulation of phosphatidylinositol 3-kinase and association with insulin receptor substrate 1 in liver and muscle of the intact rat. J Biol Chem 267: $22171-22177$.

Folli F, Saad MJA, Baker JM, Kahn CR (1993) Regulation of phosphatidylinositol 3-kinase activity in liver and muscle of animal models of insulin-resistant and insulin-deficient diabetes mellitus. J Clin Invest 92:1787-1794.

Freeman RM Jr, Plitzky J, Neel BG (1992). Identification of a human src homology 2-containing protein-tyrosine-phosphatase: a putative homolog of Drosophila corkscrew. Proc Natl Acad Sci USA 89:1 1239 11243.

Gammeltoft S, Haselbacher GK, Humbel RE, Fehlmann M, Van Obberghen E (1985) Two types of receptor for insulin-like growth factors in mammalian brain. EMBO J 4:3407-3412.

Gammeltoft S, Auletta M, Danielsen A, Larsen E, Nielsen FC, Nilsson $C$, Senen D, Wang E (1990) Insulin-like growth factors in the nervous system. Gene expression, receptor binding and actions. In: Growth factors in health and disease (Westermark B, Betsholtz C, Hokfelt T, eds), pp 227-241. Amsterdam: Elsevier.

Grant SGN, O'Dell TJ, Karl KA, Stein PL, Soriano P, Kandell ER (1992) Impaired long-term potentiation, spatial learning, and hippocampal development in fyn mutant mice. Science 258:1903-1910.

Hadari YR, Tzahar E, Nadiv O, Rothenberg P, Roberts CT Jr, LeRoith D, Yarden Y, Zick Y (1992) Insulin and insulinomimetic agents induce activation of phosphatidylinositol $3^{\prime}$-kinase upon its association with pp185 (IRS-1) in intact rat livers. J Biol Chem 267:1748317486.

Havrankova J, Roth J, Bowstein M (1978) Insulin receptors are widely distributed in the central nervous system of the rat. Nature $272: 827-$ 829.

Heidenreich KA, Toledo SP, Kenner KA (1991) Regulation of protein phosphorylation by insulin and insulin-like growth factors in cultured fetal neurons. Adv Exp Med Biol 293:379-384.

Hiles, ID, Otsu M, Volinia S, Fry MJ, Gout I, Dhand R, Panayotou G, Ruiz-Larrea F, Thompson A, Totty NF, Hsuan JJ, Courtneidge SA, Parker PJ, Waterfield MD (1992) Phosphatidylinositol 3-kinase: structure and expression of the $110 \mathrm{kd}$ catalytic subunit. Cell 70:419429.

Hill JM, Lesniak MA, Pert CB, Roth J (1986) Autoradiographic localization of insulin receptors in rat brain: prominence in olfactory and limbic areas. Neuroscience 17:1127-1138.

Hunter T (1987) A thousand and one protein kinases. Cell 50:823829.

Kasuga M, Karlsson FA, Kahn CR (1982) Insulin stimulates the phosphorylation of the 95,000-dalton subunit of its own receptor. Science 215:185-187.

King MG, Baskin DG (1991) Effect of paraformaldehyde fixation on localization and characterization of insulin-like growth factor-I (IGFI) receptors in the rat brain. Anat $\operatorname{Rec} 231: 467-472$.

Koch CA, Anderson D, Moran MF, Ellis C, Pawson T (1991) SH2 and SH3 domains: elements that control interactions of cytoplasmic signaling proteins. Science 252:668-673.

Lapetina EG, Altschuler D, Wood E, Horlick K, Jacobs S (1992) Association of phosphorylated insulin-like growth factor-I receptor with the SH2 domains of phosphatidylinositol 3-kinase p85. J Biol Chem 267:11337-11343.

Lauteriot TJ, Avarich PF, Rotwein P (1990) Divergent effects of insulin on insulin-like growth factor II gene expression in the rat hypothalamus. Endocrinology 126:392-398.

Lesniak MA, Hill JA, Kiess W, Rojeski M, Pert CB, Roth J (1988) Receptors for insulin-like growth factors I and II: autoradiographic localization in rat brain and comparison to receptors for insulin. Endocrinology 123:2089-2099.

Liu D, Rutter WJ, Wang LH (1992) Enhancement of transforming potential of human insulin-like growth factor I receptor by $\mathrm{N}$-terminal 
truncation and fusion to avian sarcoma virus UR2 gag sequence. J Virol 66:374-385.

Lowenstein EJ, Daly RJ, Batzer AG, Li W, Margolis B, Lammers R Ulrich A, Skolnik EY, Bar-Sagi D, Schlessinger I (1992) The SH2 and $\mathrm{SH} 3$ domain-containing protein GRB2 links receptor tyrosine kinases to ras signaling. Cell 70:431-442.

Massague J, Pilch PF, Czech MP (1981) Electrophoretic resolution of three major insulin receptor structures with unique subunit stoichiometries. Proc Natl Acad Sci USA 77:7137-7141.

Moss AM, Unger JW, Moxley RT, Livingston JN (1990) Location of phosphotyrosine-containing proteins by immunocytochemistry in the rat forebrain corresponds to the distribution of the insulin receptor. Proc Natl Acad Sci USA 87:4453-4457.

Myers MG Jr, White MF (1993) The new elements of insulin signaling. Insulin receptor substrate- 1 and proteins with $\mathrm{SH} 2$ domains. Diabetes 42:643-650.

Myers MG Jr, Sun XJ, Cheatham B, Jachna BR, Glasheen EM, Backer JM, White MF (1993) IRS-1 is a common element of insulin and IGF-1 signaling to the phosphatidylinositol 3'-kinase. Endocrinology 132:1421-1430

Nairn AC, Hemmings HC, Greengard P (1985) Protein kinases in the brain. Annu Rev Biochem 54:931-976.

Obermeier A, Lammers R, Wiesmuller K-H, Jung G, Schlessinger J, Ullrich A (1993) Identification of the $t r k$ binding sites for SHC and phosphatidyl inositol 3'-kinase and formation of a multimeric signaling complex. J Biol Chem 268:22963-22966

Ocrant I, Valentino KL, Eng LF, Hintz RL, Wilson DM, Rosenfeld RG (1988) Structural and immunohistochemical characterization of insulin-like growth factor I and II receptor in the murine central nervous system. Endocrinology 123:1023-1033.

Pang, DT, Sharma BR, Shafer JA (1985) Purification of the catalytically active phosphorylated form of insulin receptor kinase by affinity chromatography with $O$-phosphotyrosil-binding antibodies. Arch Biochem Biophys 242:176-186.

Posner BI, Kelly PA, Shiu RPC, Friesen HG (1974) Studies of insulin, growth hormone and prolactine binding: tissue distribution, species variations and characterization. Endocrinology 95:521-531.

Puro DG, Agardh E (1984) Insulin-mediated regulation of neuronal maturation. Science 225:1170-1172.

Rosenzweig SA, Zetterstrom C, Benjamin A (1990) Identification of retinal insulin receptors using site-specific antibodies to a carboxyterminal peptide of the human insulin receptor $\alpha$ subunit. Upregulation of neuronal insulin receptor in diabetes. $J$ Biol Chem 265: 18030-18034.

Rothenberg PL, Lane WS, Karasik A, Backer JM, White MF, Kahn CR (1991) Purification and partial sequence analysis of $\mathrm{pp} 185$, the major cellular substrate of the insulin receptor tyrosine kinase. J Biol Chem 266:8302-8311.

Saad MJA, Araki E, Mirapleix M, Rothenberg PL, White MF, Kahn CR (1992) Regulation of insulin receptor substrate-1 in liver and muscle of animal models of insulin resistance. J Clin Invest 90:18391849.

Saltiel AR, Ohmichi M (1993) Pleiotropic signaling from receptor tyrosine kinases. Curr Opin Neurobiol 3:352-359.

Schemer J, Raizada MK, Masters BA, Ota A, Lerdith D (1987a) Insulin-like growth factor-I receptors in neuronal and glial cells. J Biol Chem 262:7693-7699.

Schemer J, Adamo M, Wilson GL, Heffez D, Zick Y, Leroith D (1987b) Insulin and insulin-like growth factor-I stimulate a common endogenous phosphoprotein substrate (pp185) in intact neuroblastoma cells. J Biol Chem 262:15476-15482.
Schwartz MW, Sipols AJ, Kahn SE, Latterman DP, Taborsky G Jr, Berchan RN, Wood SC, Porte D Jr (1990) Kinetics and specificity of insulin uptake from plasma into cerebrospinal fluid. Am J Physiol 259:E378-E383.

Schwartz MW, Ficlewicz DP, Baskin DG, Wood SC, Porte D Jr (1992) Insulin in the brain: a hormonal regulator of energy balance. Endocr Rev 13:387-414.

Shu S, Ju G, Fan L (1988) The glucose oxidase-DAB-nickel method in peroxidase histochemistry of the nervous system. Neurosci Lett 85:169-171.

Skolnik EY, Margolis B, Mohammadi M, Lowenstein E, Fischer R, Drepps A, Ullrich A, Schlessinger J (1991) Cloning of PI-3 kinaseassociated p85 utilizing a novel method for expression/cloning of target proteins for receptor tyrosine kinases. Cell 65:83-90.

Soltoff SP, Rabin SL, Cantley LC, Kaplan DR (1992) Nerve growth factor promotes the activation of phosphatidylinositol 3-kinase and its association with the $t r k$ tyrosine kinase. J Biol Chem 267:1747217477.

Sun XJ, Rothenberg P, Kahn CR, Backer JM, Araki E, Wilden P, Cahill DA, Goldstein BJ, White MF (1991) Structure of the insulin receptor substrate IRS-1 defines a unique signal transduction protein. Nature 352:73-77.

Sun XJ, Miralpeix M, Myers MG Jr, Glasheen EM, Backer JM, Kahn CR, White MF (1992) Expression and function of IRS-1 in insulin signal transmission. J Biol Chem 267:22662-22672.

Sun XJ, Crimmins DL, Myers MG Jr, Miralpeix M, White MF (1993) Pleiotropic insulin signals are engaged by multisite phosphorylation of IRS-1. Mol Cell Biol, in press.

Theodosis DT, Poulain DA (1993) Activity-dependent neuronal-glial and synaptic plasticity in the adult mammalian hypothalamus. Neuroscience, in press.

Unger JW, McNeill TH, Moxley RT, White MF, Moss AM, Livingston JN (1989) Distribution of insulin receptor-like immunoreactivity in the rat forebrain. Neuroscience 31:143-157.

Unger JW, Livingston JN, Moss AM (1991a) Insulin receptors in the central nervous system: localization, signaling mechanisms and functional aspects. Prog Neurobiol 36:343-362.

Unger JW, Moss AM, Livingston JN (1991b) Immunohistochemical localization of insulin receptors and phosphotyrosine in the brainstem of the adult rat. Neuroscience 42:853-861.

Wang L, Keegan AD, Li W, Lienhard GE, Pacini S, Gutkind JS, Myers MG, Sun XJ, White MF, Aaronson SA, Paul WE, Pierce JH (1993a) Common elements in IL4 and insulin signaling pathways in factor dependent hematopoietic cells. Proc Natl Acad Sci USA 90:40324036.

Wang LM, Myers MG, Sun XJ, Aaronson SA, White MF, Pierce IH (1993b) Expression of the principal phosphotyrosine substrate of the insulin receptor, IRS-1, restores insulin- and IL-4-mediated mitogenesis. Science, in press.

White MF, Maron R, Kahn CR (1985) Insulin rapidly stimulates tyrosine phosphorylation of a $\mathrm{M}_{\mathrm{r}} 185,000$ protein in intact cells. $\mathrm{Na}-$ ture 318:183-186.

Whitman M, Kaplan DR, Schaffausen B, Cantley L, Roberts TM (1985) Association of phosphatidylinositol kinase activity with polyoma middle-T competent for transformation. Nature 31 5:239-242.

Yonezawa K, Yokono K, Shii K, Ogawa W, Ando A, Hara K, Baba S, Kaburagi Y, Yamamoto-Honda R, Momomura K, Kadowaki T, Kasuga $M$ (1992) In vitro association of phosphatidylinositol 3-kinase activity with the activated insulin receptor tyrosine kinase. J Biol Chem 267:440-446. 